\title{
Sustainable development start-ups as a new category of enterprises in Poland
}

\author{
Aleksandra Stanek-Kowalczyk
}

\begin{abstract}
A B S T R A C T
Objective: The objective of the article is to review entities operating in Poland on the basis of sustainable business models in order to determine the scale and development potential for this phenomenon and to define the profile of this type of enterprises operating in Poland.

Research Design \& Methods: The study was based on a desk research analysis divided into two phases: Part one: creation of a picture of the positive impact start-up market, taking into account the following data: establishment year of the enterprise, the city, in which the business is registered, the industry, in which the company operates, type of activity. Part two: creation of a picture of the positive impact startup market in terms of the use of new technologies. Source of data: the database of Positive Impact Startups, prepared and published by Koźmiński Business Hub, which is the only list of enterprises operating in Poland based on sustainable business models.
\end{abstract}

Findings: Based on the analysed data, a profile of a Positive Impact Start-up was created with the most typical characteristics of this type of enterprise. A profile is a set of features that are most frequent within each analysed category.

Implications \& Recommendations: The study describes a new type of enterprises in Poland, including the scale of development of such type of enterprises and their characteristics. That can help the policy-makers in proper definition of business landscape in Poland - both today and in a near future - and defining the regulatory needs of such type of enterprises.

Contribution \& Value Added: The study contributes to the literature on the sustainable business models, by analysing the development and characteristics of sustainable business model based enterprises operating in Poland, as well as defining the profile of such enterprise operating in Poland.

\begin{tabular}{llll}
\hline $\begin{array}{l}\text { Article type: } \\
\text { Keywords: }\end{array}$ & research article & & \\
JEL codes: & start-ups; sustainable business model; sustainability; entrepreneurship; innovation \\
\multicolumn{1}{c}{ Received: 4 January 2021 } & Revised: 6 May 2021 & Accepted: 11 May 2021 \\
\hline
\end{tabular}

\section{Suggested citation:}

Stanek-Kowalczyk, A. (2021). Sustainable development start-ups as a new category of enterprises in Poland. International Entrepreneurship Review, 7(2), 67-83. https://doi.org/10.15678/IER.2021.0702.06

\section{INTRODUCTION}

The pace of changes in the economic environment forces organizations to constantly search for new solutions and implement business innovation models, considered to be a source of competitive advantage. These include innovations implemented as part of individual elements of the business models, but also interactions between them. Innovations allow to strategically integrate sustainable development into business models. Due to the growing importance of the subject of sustainable development and the more frequent incorporation of environmental and social aspects into business models, a new concept of sustainable business model (SBM) has emerged. Sustainable business models are considered as a form of innovative business models and involve the reduction of negative impact and generation of various benefits (Yip \& Bocken, 2018). The value proposition includes measurable social, environmental 
and economic values (Boons \& Lüdeke-Freund, 2013), and is based on capitals other than just the financial one, that can affect enterprise's performance and its development (Le Trinh, 2019).

The functioning of enterprises based on sustainable business models in Poland had not been the subject of empirical research until 2019. There had been no analyses of the scale of this phenomenon and the characteristics of entities operating in Poland and based on business models that take into account social and environmental aspects. In 2019, Koźmiński Business Hub published the Positive impact start-ups report. Radical social innovation (Rok et al., 2019) along with a database of enterprises using sustainable business models.

The purpose of the research is to review entities operating in Poland on the basis of sustainable business models in order to determine the scale and development potential for this phenomenon and to define the profile of this type of enterprises operating in Poland by searching for answers to the following questions:

RQ1: What is the average age of enterprises operating on the basis of sustainable business models?

RQ2: In which city enterprises operating on the basis of sustainable business models are most often established?

RQ3: In which industry enterprises operating on the basis of sustainable business models are most often established?

RQ4: Do enterprises operating on the basis of sustainable business models use new technologies?

The research was conducted based on the analysis of existing data from the database of Positive Impact Start-ups, prepared and published by Koźmiński Business Hub - the only list of enterprises operating in Poland based on sustainable business models. The data were analysed using descriptive statistics methods, and the results of the analyses were presented in the form of column charts.

The article begins with literature review containing review of the literature on sustainable business models as a new type of business models then the methodology applied to the study was presented, results of the study and conclusions as well as areas for further research.

\section{LITERATURE REVIEW}

\section{Evolving Concept of Sustainable Development}

The concept of sustainable development has been used in both academic and business discourse for several dozen year. According to some scientists, it has its roots in the environmental ideology (Balbinot \& Borim-De-Souza, 2012; Lélé, 1991), while others see the origins of the concept in the 1987 report of the World Commission on Environment and Development (WCED), entitled Our Common Future, which defined sustainable development as "development that meets the needs of the present without compromising the ability of future generations to meet their own needs" (World Commission on Environment and Development, 1987, p. 16). The proposed definition includes two main factors related to sustainable development: needs and restrictions. It stresses the need to meet people's basic needs, especially the weaker ones, while at the same time emphasizing the restrictions related to the limited availability of resources. Skowroński (2006) renders this definition more precise by adding that the mechanism of sustainable development comes down to the achievement of three basic goals: economic (related to satisfying the basic material needs, with the use of technologies that do not have a negative impact on the environment), ecological (related to preventing environmental degradation, as well as social and humanitarian (related to the provision of basic social needs of people).

Regardless of its origin and definition, sustainable development had initially been developed as a macroeconomic concept. Over time, however, it came to be used also in relation to business organizations (Stanek-Kowalczyk, 2012). In 1998, John Elkington introduced the concept of Triple Bottom Line, which assumes that organizations should focus on integrating their impact on the environment in terms of the social, environmental and economic aspects (Elkington, 1998). The suggested approach stands in opposition to the classical concepts and approach that views enterprises as organizations whose task is to focus on generating profit. It has added a new dimension to the understanding of sustainable development, on the basis of which the concept of corporate sustainability appeared in 
the literature as a response to a number of challenges brought by the 20th century, such as: globalization, social injustice or environmental degradation (Christofi et al., 2012).

Although the very concept of sustainable development and its scope have been the subject of discussions and scientific publications, there is no single understanding of this term, which, in addition, is constantly evolving (Kagawa, 2007). Numerous definitions and approaches to this subject differ also in terms of their subject matter (Sheehan et al., 2014).

\section{Sustainable Business Models}

The concept of the business model has been discussed in the literature since the 1990s. Business models help to explain how a company creates and maintains value (Battistella et al., 2017; Chesbrough, 2007; Foss \& Saebi, 2017; Zott et al., 2011). Teece (2010) defines it as a way in which organizations transform their resources and competences into economic value, while Boons and Lüdeke-Freund (2013) explain it is a link between a given enterprise and the wider production and consumption system, in which it operates. Osterwalder and Pigneur view business models as a set of specific elements (Osterwalder \& Pigneur, 2010), while Zott and Amit (2011) present an action perspective, where the model includes a selection of actions ("what"), the structure of the system of actions ("how"), as well as information about who undertakes the actions ("who").

Each business model is specific to a given company due to the dependencies and relationships between the various elements of its value chain. Such an approach does not preclude the existence of a set of specific standard elements that can be adapted to a particular organization, according to its needs and nature. Examples of standard element sets include the Business Model Canvas, made up of 9 elements, on the basis of which one can build and adapt business models to any organization, and a simplified business model diagram with three main elements: value proposition, creation, delivery, and maintenance (Figure 1).

Value proposition
Product/service, customer
segments and relationships

\section{Value creation and delivery \\ Key actions, resources, chan- nels, partners, technologies}

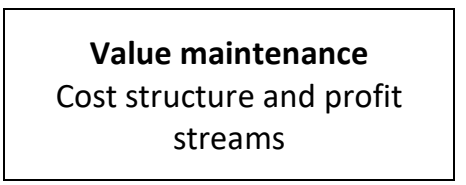
streams

Figure 1. Simplified diagram of the business model

Source: Bocken et al. (2014, s. 143) based on Richardson (2008) and Osterwalder et al. (2005).

The pace of changes in the economic environment forces organizations to constantly search for new solutions and implement business innovation models, which are considered a source of competitive advantage. These include innovations implemented as part of individual elements of the business models, but also interactions between them. Innovations allow to strategically integrate sustainable development into business models. If enterprises are to fully contribute to sustainable development it is not enough to undertake non-strategic partial actions as part of selected business functions, but it is also necessary to redefine the concept of business models, incorporating into them social and environmental aspects (Reinhardt et al., 2019). That will allow for a sustainable growth (Wach, 2020). Taking into account the changes in the socio-economic environment, including the challenges related to sustainable development, companies' approaches to value creation should best be analysed in the context of tri-profit value, namely social, environmental and business benefits, where the concept of value has a wider definition than mere profit (Bradley et al., 2020; Press et al., 2020).

Due to the growing importance of the subject of sustainable development and the more frequent incorporation of environmental and social aspects into business models, a new concept of sustainable business model (SBM) has emerged. The last ten years have seen the development of an approach based on sustainable business models (Reinhardt et al., 2019) as well as research on how businesses incorporate such models into their operations (Press et al., 2020).

Sustainable business models are considered as a form of innovative business models and involve the reduction of negative impact and generation of various benefits (Yip \& Bocken, 2018). Social and environmental aspects make it possible to find new market niches, new markets for products and services, 
and to support the brand or increase the company's market value (Galpin et al., 2015). In a sustainable business model the value proposition includes measurable social, environmental and economic values (Boons \& Lüdeke-Freund, 2013), which is why it can be a useful scheme for changing the system of an organization and is of key importance in terms of creating opportunities for enterprises to take up the global challenges related to sustainable development. It is also considered as a potent lever, capable of changing the global business system (Prendeville \& Bocken, 2017). It focuses on conducting business activities in a new way that disrupts the existing rules of competitiveness and can be the foundation for creating new business models and a new approach to value creation (Yip \& Bocken, 2018).

The lack of a single, consistent definition of sustainable development results in the lack of a standard approach to measuring and implementing this concept (Smith \& Sharicz, 2011), and thus the lack of a single, standard sustainable business model. Press, Robert and Maillefert define such models as those that aim at operating in a more sustainable way and create more sustainable solutions. While based on business models, they also take into account possible negative social and environmental impact of the actions taken, opting for more sustainable solutions (Press et al., 2020). Rafiei and RicardezSandoval claim that sustainable enterprises should strive at protecting nature and people, without sacrificing economic efficiency and innovation (Rafiei \& Ricardez-Sandoval, 2020). This view emphasizes that companies based on sustainable business models are still enterprises operating for profit. What is different is that in conventional business models, profit is the only goal of the business activity, while sustainable models add to the economic aspect also social and environmental dimensions.

In their suggested definition of a sustainable business model, Schaltegger et al. (2016) refer to a simplified scheme of a business model based on three elements related to value creation and maintenance (see Figure 2), stating that a sustainable business model helps to analyse, describe, manage and communicate the organization's business model, which - apart from creating economic values - serves to create and deliver social and environmental values as well.
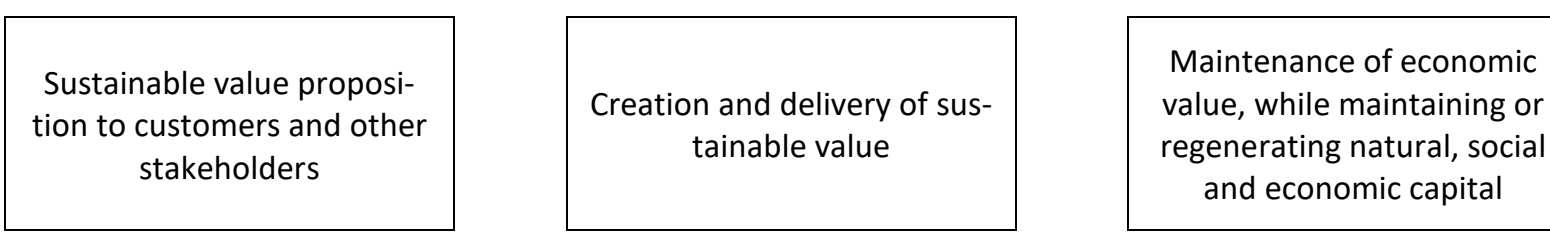
value, while maintaining or regenerating natural, social and economic capital

Figure 2. Simplified diagram of a sustainable business model

Source: adapted from Schaltegger, Hansen, and Ludeke-Freund (2016).

According to Reinhardt et al., the concept of a sustainable business model reflects an approach that integrates the foundations of sustainable development with conventional business models and modifies them in order to create economic, social and environmental values (Reinhardt et al., 2019), which is in line with the approach proposed by Schaltegger et al. (2016). Marioka, Evans and Carvalho, in turn, propose an approach based on the Schaltegger model, in which they indicate the dimensions that should be analysed in relation to the three elements of the sustainable business model. These include (Morioka et al., 2016, p. 662):

- stakeholder satisfaction,

- strategic motivation,

- business processes,

- possibilities,

- stakeholders' contribution.

The suggested approach allows to determine whether the model is implemented - on the one hand - in line with the key elements of the business model, and - on the other - in line with the key processes.

According to Bocken $(2013 ; 2014 ; 2016)$, the concept of a sustainable business model redefines the role of enterprises and their importance for the society and the environment. The definition proposed by the author goes a step further than the earlier definitions, which indicated the social 
and environmental goals as equivalent to the economic one. Bocken argues that providing business and social benefits should be prioritized over economic profits (e.g. value for investors). These goals should be achieved through integration and cooperation with local communities, as well as other stakeholder groups, which, as the author indicates, represents a change in comparison to conventional business models, in which the customer was the main beneficiary of the company's business operations (Bocken et al., 2014). Bocken proposes 8 subcategories for sustainable business models, called archetypes. These include (Bocken et al., 2014, p. 48):

1. maximise material and energy efficiency,

2. create value from 'waste',

3. substitute with renewables and natural processes,

4. deliver functionality, rather than ownership,

5. adopt a stewardship role,

6. encourage sufficiency,

7. re-purpose the business for society/environment,

8. develop scale-up solutions.

The above-mentioned archetypes are diverse in terms of the scope and type of proposed actions and relate to both the entire business model of the organization as well as its selected elements or processes. For instance, "creating value from waste" focuses on how a product is made, "adopting a stewardship role" refers to an approach to business management, while "maximising material and energy efficiency" concerns the processes in the organization. Viciunaite and Alfne (2020) point out that most of the archetypes proposed by Bocken focus on the production system and little attention is paid to the consumption system.

\section{Selected Economic Concepts as the Basis of Sustainable Business Models}

The source and foundation for creating sustainable business models can be broader economic concepts based on the assumptions of sustainable development, such as, for example, circular economy.

Circular economy represents a transition from a linear model based on the production of a product, its use and disposal, to a circular model under which products are returned to use in various forms. This approach is aimed not only at extending the life cycle of products, but - above all - at reducing waste generation (Euroactiv.pl, 2018). Business models based on circular economy not only create sustainable value and support proactive multi-stakeholder management in the long run, but also slow down, reduce and close the resources gap (Bocken et al., 2016).

Among the important economic concepts that are based on new technologies and are considered to be the basis of sustainable business models, there is also the concept of sharing economy. The sharing economy addresses the need for efficient access and use of resources. According to McKinsey's report, an average European car remains parked $92 \%$ of the time, average office space in Europe is used $35-50 \%$ of the time and $31 \%$ of food is wasted along the entire value chain (Ellen MacArthur Foundation \& McKinsey Center for Business and Environment, 2015).

The concept of temporary access to services is not new. It had already been mentioned in literature 20 years ago as part of the servilization concept, where the sharing economy was diagnosed as a subsystem of this concept (Ciulli \& Kolk, 2019). Oxford Dictionary defines it as sharing resources by individuals for free or for a specific fee, usually via the Internet. Thus, the concept of ownership, which underlies the conventional model of the economy, turns into the concept of experience, and the sharing economy is the umbrella model for any alternatives to traditional ownership-based solutions (Dabbous \& Tarhini, 2019).

Among the positive aspects of business models based on the sharing economy, what is most commonly indicated is the efficient use of resources, which have so far been used in an ineffective manner. In the social dimension, the sharing economy has a positive impact on solidarity and forging social bonds between individuals, and creates added value by making products available to people who cannot afford them (Ciulli \& Kolk, 2019). Models based on the sharing economy have been recognized as sustainable business models (Bocken et al., 2014). 


\section{Challenges Related to the Implementation of Sustainable Business Models}

Although there is an increasing number of literature sources on the subject of business models, their concepts and definitions, there is still little debate about what the transition to sustainable development looks like and how sustainable business models in organizations emerge and grow. Research shows that individual elements of business models are - to various extent - taken into account by companies, but that sustainable business models are not implemented as such the conceptual level (Press et al., 2020). This means that the undertaken actions are partial and related to selected processes, products or other areas of the company's business operation.

One of the challenges for the implementation of sustainable business models are the pre-existing unsustainable models, which may promote certain patterns, processes and structures or pressure for short-term profit (Yip \& Bocken, 2018). For organizations that are in the process of transformation of their business model into a sustainable one, implementation of such an approach may therefore pose a greater challenge than for those that have been based on the principles of sustainable development from the start.

Another limitation related to the implementation of sustainable business models is the lack of uniform implementation tools. Even though their number is increasing, it is still insignificant and usually focuses on specific processes or process elements (Reinhardt et al., 2019). Examples include the value mapping tool proposed by Bocken et al. (2013), the "flourishing canvas" model (Upward \& Jones, 2016) or the Triple Layered Business Model Casnvas (Joyce \& Paquin, 2016).

Another challenge indicated by the academic community is the fact that the suggested sustainable business models are often complex and complicated, which poses difficulties in terms of their application for both scientists and entrepreneurs (Sala et al., 2015). Thus, models designed to facilitate understanding and implementation of sustainable development are often conceptual, have a limited scope and do not reflect organizational complexity (Kolk \& Mauser, 2002).

There is no full agreement in the academic community regarding the benefits related to implementation of sustainable business models. In addition to a number of publications indicating sustainable models as an important and positive trend, there are also voices that treat this subject in a cautious manner, pointing out, for instance, transaction costs related to the implementation of such an approach, the costs of sustainable development or opportunism (Beckmann et al., 2014; Sancha et al., 2016). Some scholars also point to the fact that in the case of certain measures and solutions, only their positive aspects are emphasized, while disregarding the negative ones. For example, innovation and technology transfers can have a negative impact on the environment (Ferreira et al., 2020).

Based on the literature review the following research questions were formulated:

- What is the average age of enterprises operating on the basis of sustainable business models in Poland?

- In which city enterprises operating on the basis of sustainable business models are most often established?

- In which industry enterprises operating on the basis of sustainable business models are most often established?

- Do enterprises operating on the basis of sustainable business models use new technologies?

in order to determine the scale and development potential for this phenomenon and to define the profile of this type of enterprises operating in Poland. 


\section{RESEARCH METHODOLOGY}

\section{Sustainable Development Start-Ups - Development of a New Category of Enterprises in Poland}

The functioning of enterprises based on sustainable business models in Poland had not been the subject of empirical research until 2019. There had been no analyses of the scale of this phenomenon and the characteristics of entities operating in Poland and based on business models that take into account social and environmental aspects.

In 2019, Koźmiński Business Hub published the Positive impact start-ups report. Radical social innovation (Rok et al., 2019) along with a database of enterprises using sustainable business models. The database of Positive Impact Start-ups included 356 entities.

\section{Purpose of the Research}

The purpose of this research is to review entities based on sustainable business models, in order to determine the scale and development potential for this phenomenon and to define the profile of this type of enterprises operating in Poland.

The database of Positive Impact Start-ups, prepared and published by Koźmiński Business Hub, is the only list of enterprises operating in Poland based on sustainable business models, and was, therefore, used as a source of analysis for the purposes of this publication.

The authors of the Report and the Database define Positive Impact Start-ups as "an economic activity, which - through innovations related to sustainable development, the use of technology and increasing the level of reliability and efficiency - allow people acting with passion for the common good to achieve a rapid increase in the value of the company/organization, as well as the quality of life and the environment within its scope of influence" (Rok et al., 2019, p. 20).

According to the definition mentioned above, a Positive Impact Start-up should:

- undertake economic activity (though it does not necessarily have to be an enterprise),

- be innovative, so as to contribute to the achievement of the global Sustainable Development Goals,

- use new technologies,

- act ethically and efficiently,

- search for a scalable, repeatable business model and focus on a rapid development in the assumed direction,

- maximize the positive impact on the environment, within its capabilities and scope of activity.

In order to build a more comprehensive profile of the Database, the entities were analysed not only in relation to statistical data such as the age of the enterprise, the location in which the enterprise was established and the industry in which it operates, but also in relation to such aspects as the use of new technologies. It is an element of the proposed definition of the Positive Impact Start-ups. This paper did not analyse innovation understood as a contribution to the Sustainable Development Goals.

\section{Initial Analysis}

According to the definition, a Positive Impact Start-up should undertake economic activity, though it does not necessarily have to be an enterprise. For the purposes of this analysis, this criterion was disregarded. Social organizations (associations or foundations) were excluded, as the authors considered that their purpose was to solve specific social or environmental problems, and not to generate profit. Any economic activity carried out by non-governmental organizations is an additional activity. Thus, such organizations do not integrate social, environmental and economic aspects. The economic aspect is a tool that supports - to a specific, limited extent - the implementation of social and environmental goals. In addition, the legal form also entails a number of additional rights and obligations that make business and social organizations incomparable. These differences concern both the limitations related to the economic activity and generating profits, as well as the rights and benefits resulting from social activity. Social cooperatives - entities combining the features of enterprises and non-governmental organizations - were treated as an exception. 
In order to ensure terminological and definitional consistency, the author of the paper chose to use the term Positive Impact Start-ups, proposed by the authors of the report and the Positive Impact Start-up database.

Before conducting the substantive analysis, the enterprises in the database were analysed in terms of four operational criteria:

1. The existence of the enterprise on the market: Enterprises which do not figure in the relevant registers (CEIDG or KRS), and/or for which information on the Internet could not be found (their official website either did not exist or was not working, and/or their profiles on social media networks have not been updated at least for the last six months).

2. Country of business registration: It was assumed that since the purpose of the analysis was to show the condition of the market of enterprises operating under the sustainable development model in Poland, enterprises registered in other countries should be excluded.

3. Business owner: Enterprises owned by a different, larger entity were excluded from the analysis.

4. Legal form: Social organizations (associations or foundations) were excluded, leaving in the database only enterprises operating in any form.

After applying the above-mentioned criteria, 213 entities remained in the database for analysis.

\section{Concept and Research Plan}

The analysis was divided into two parts, on the basis of which it was possible to review the Positive Impact Start-ups in Poland and construct a profile of this type of enterprise.

\section{Part One: Features of Positive Impact Start-ups}

The purpose of this part of the analysis was to create a profile of the positive impact start-up market, taking into account such basic data as:

- establishment year of the enterprise: For the sake of transparency of the presented data, all companies that were established before 2015 have been included.

- the city, in which the business is registered: For the sake of transparency, cities with at least 2 positive impact start-ups have been established. The other cities were considered altogether.

- the industry, in which the company operates: For the purposes of this article, the companies listed in the positive impact start-up database have been divided on the basis of the industries, in which they operate, with the use of the division adopted by the Warsaw Stock Exchange (WSE), and not the conventionally used Polish Classification of Activities (PKD). The classification suggested by the WSE takes into account the recipients of products and services, and not the method of production, which is the basis for the classification of the Polish Classification of Activities. Due to the innovative nature of the Positive Impact Start-ups, it was decided that the WSE classification will be more appropriate due to the analysis of recipients. As part of this classification, 8 macro-sectors have been distinguished:

1. financial,

2. fuels and energy,

3. chemistry and raw materials,

4. industrial and construction production,

5. consumption goods,

6. trade and services,

7. health,

8. technologies.

Within each macro-sector, sectors and subsectors have been distinguished. The results of the analyses were presented at the level of sectors, with references - in selected cases - to the level of macro-sectors or subsectors.

Type of activity: For the purposes of the research, the enterprises were divided into two categories: manufacturing enterprises and service enterprises.

Due to the specific nature of business activities conducted by Positive Impact Start-ups, which include sustainability aspects, a classification was also introduced according to theses aspects included. Eco- 
nomic aspects were assumed in the business operation of each enterprise. The analysis took into account the incorporation of social or environmental aspects by companies, or - in some cases - both of them.

\section{Part two: Positive Impact Start-ups in Terms of the Use of New Technologies}

The purpose of the second part of the analysis was to create a profile of the positive impact startup market in terms of the use of new technologies. The use of new technologies is an element of the definition of a positive impact start-up, proposed by the authors of the report Positive Impact Start-up. Radical Social Innovation.

The group of enterprises that make use of new technologies includes both enterprises that are creating products or providing services on the basis of new technological solutions developed by other entities or are based on solutions developed internally. Online shopping has been excluded due to the widespread use of this type of solutions.

The purpose of this article was to review and describe the positive impact start-up market based on the available database with the use of descriptive statistics. The results were presented in the form of histograms.

\section{RESULTS AND DISCUSSION}

\section{Part One: Features of Positive Impact Start-ups}

Despite the fact that a sustainable business model is a relatively new concept, enterprises that integrate social and environmental aspects into their business operation have been present on the Polish market for a long time. The first enterprises included in the Positive Impact Start-ups database were established in the 1990s. In total, almost $40 \%$ of enterprises had been established 5 or more years ago. This proves that social and environmental issues were important to people who were establishing their own businesses long before related concepts were developed in the scientific and business discourse.

The year 2015, due to the announcement of the 2030 Agenda and the Sustainable Development Goals, was a breakthrough moment for the subject of sustainable development, which became an important topic not only in academic, but also in public and business discussions. This likely had an impact on the increasing number of Positive Impact Start-Ups established in Poland. Already since 2011, there had been over a dozen of new ones per year, but since 2015 that number has grown to over 20 per year (see Figure 3).

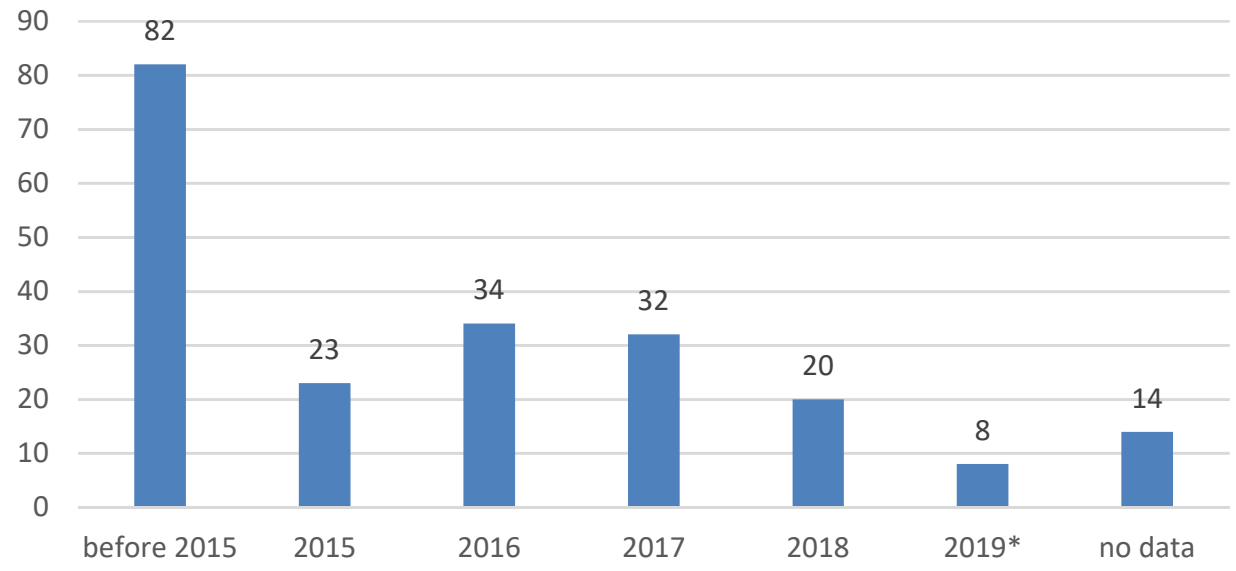

* Data for 2019 is incomplete. It includes firms listed in the Positive Impact Start-ups database, published in April 2019.

Figure 3. Number of Positive Impact Start-ups broken down by the years in which they were established ${ }^{1}$ Source: own elaboration $(n=213)$. 
In total, more than half of the start-ups were established in 2015 and after that year. Based on the formula:

where:

$$
\bar{x}=\frac{x_{1}+\cdots x_{n}}{n}
$$

$x$ - in number of positive impact star-ups established in the given year;

$n$ - number of analysed years.

The average age of Positive Impact Start-ups was calculated, which was 4 years and 8 month. The analysis shows that Positive Impact Start-ups are being established mostly in large cities. Most enterprises of this type were established in Warsaw (76), Kraków (24), Wrocław (15) and Poznań (11) (see Figure 4). This is probably due to greater awareness of the inhabitants of large cities regarding social and environmental issues, which translates both into the number of enterprises established and the number of potential consumers using products and services offered by them. Another reason may be the fact that these are cities, where large, also international corporations are operating that are potential clients for Positive Impact Start-ups. The third possible reason is the higher income of people living and working in large cities, especially in Warsaw. Good financial situation makes it possible to focus on other aspects of the products or services while making decisions related to purchases, not only the price criterion.

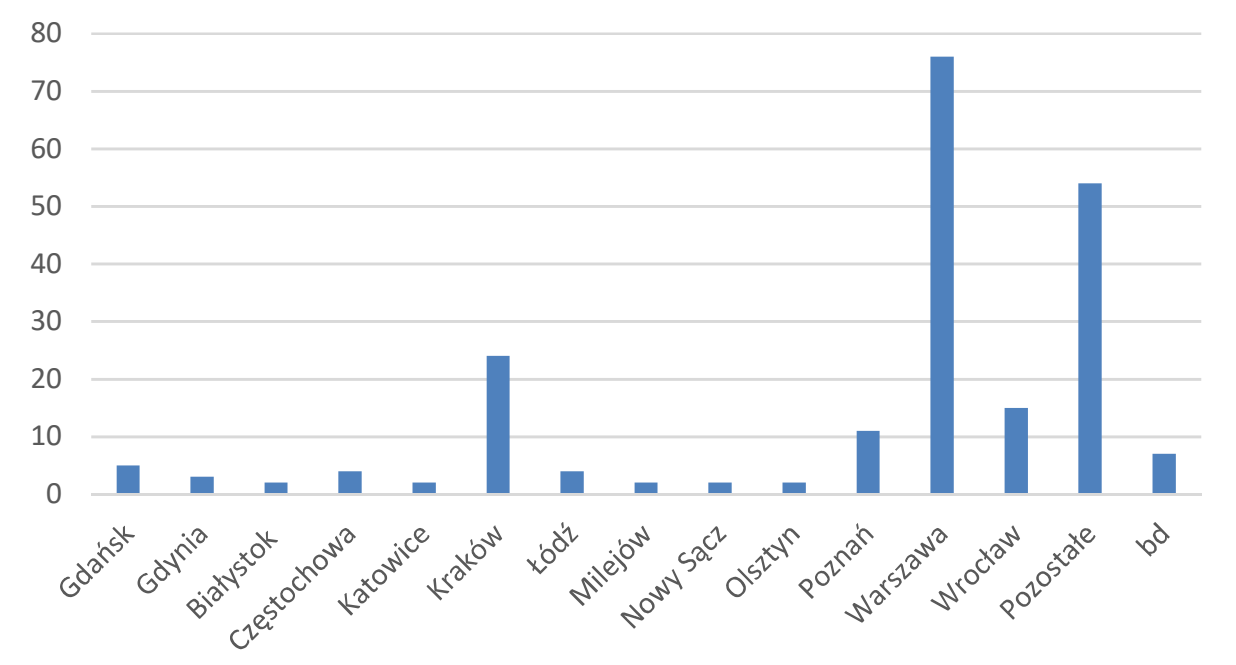

Figure 4. Number of Positive Impact Start-ups broken down by cities, in which they are registered Source: own elaboration $(n=213)$.

The Positive Impact Start-ups analysed operate mainly in two macro sectors: consumer goods (100 entities) and trade and services ( 85 entities). In total, they operate in six out of eight macro-sectors.

It should be noted that a significant part of enterprises within particular sectors was assigned to the category "other" (almost every third enterprise, which makes for 79 enterprises). This shows that the existing classification systems of enterprises do not reflect the actual scope of their business activities. This is especially visible in the case of enterprises operating on the basis of innovative business models, including sustainable business models. As a result, it is impossible to create a reliable image of the scope of activities of Positive Impact Start-ups, since too many of them remain outside the defined categories of activities.

Positive Impact Start-ups are mainly manufacturing companies (129 offer products, 79 offer services and 5 offer both products and services), which stands in opposition to what is commonly observed in the economy, where employment in services is almost twice as high as in industry (GUS, 2019). 


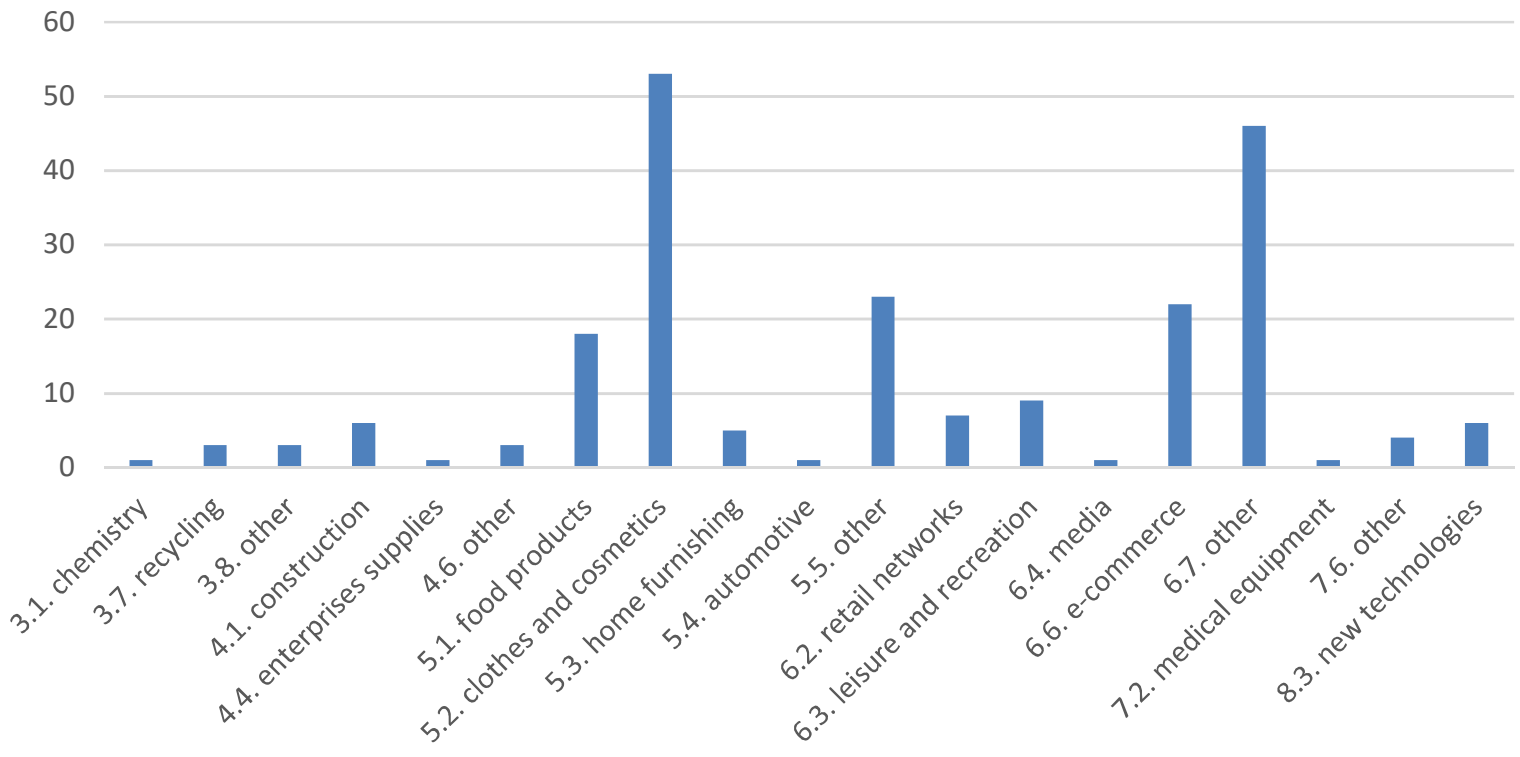

Figure 5. Number of Positive Impact Start-ups broken down by industries Source: own elaboration $(n=213)$.

Viciunaite and Alfnesa (2020) argue that consumers are interested in the aspects of sustainable development that are at the beginning of the value chain. What is important is the origin of raw materials or the manufacturing methods of a given product. Positive Impact Start-ups offering a sustainable product respond to the need defined in such a way, so a larger number of manufacturing companies may be a response to market demand.

The most common products offered by Positive Impact Start-Ups include clothing and cosmetics (53 companies), products that do not fit into any category ( 23 companies) and food products ( $18 \mathrm{com}$ panies). Most companies offering services operate in the trade and services sector (39 companies), but their business activities have not been assigned to any of the subsectors. 22 companies ${ }^{2}$ operate in online sales of products that meet specific environmental and social criteria (see Figure 6). The predominance of services in enterprises operating in the trade (including online trade), as well as recreation and leisure sectors, reflects the specificity of these enterprises and the nature of their business.

It is worth to point out that the largest number of Positive Impact Start-ups offer clothing and cosmetic products. Although it is the most numerous group among Positive Impact Start-ups, at the same time - in the scale of the whole industry, in which there were over 22,000 companies employing almost 188,000 people in 2016 alone (KPMG, 2018) - it is insignificant, which means that regardless of the numerical distribution within the analysed group, taking into account its current size, it is not possible to draw conclusions based on the results obtained, neither for the entire market nor for individual industries. The number of such entities is too small.

Environmental aspects underlie the business operation of Positive Impact Start-ups much more often than social aspects. The environmental aspects were incorporated by 96 organizations, while the social aspects - by 32 , which means that a significant part of enterprises (85) take into account both of them. More frequent incorporation of environmental aspects into business models, as compared to social aspects, may be the result of a growing environmental awareness in Poland, with a simultaneous sense of security in terms of social and economic aspects, reflected, for instance, in in the low unemployment rate or universal access to education and health care.

2 This figure does not include manufacturers who not only manufacture but also sell their products via the Internet 


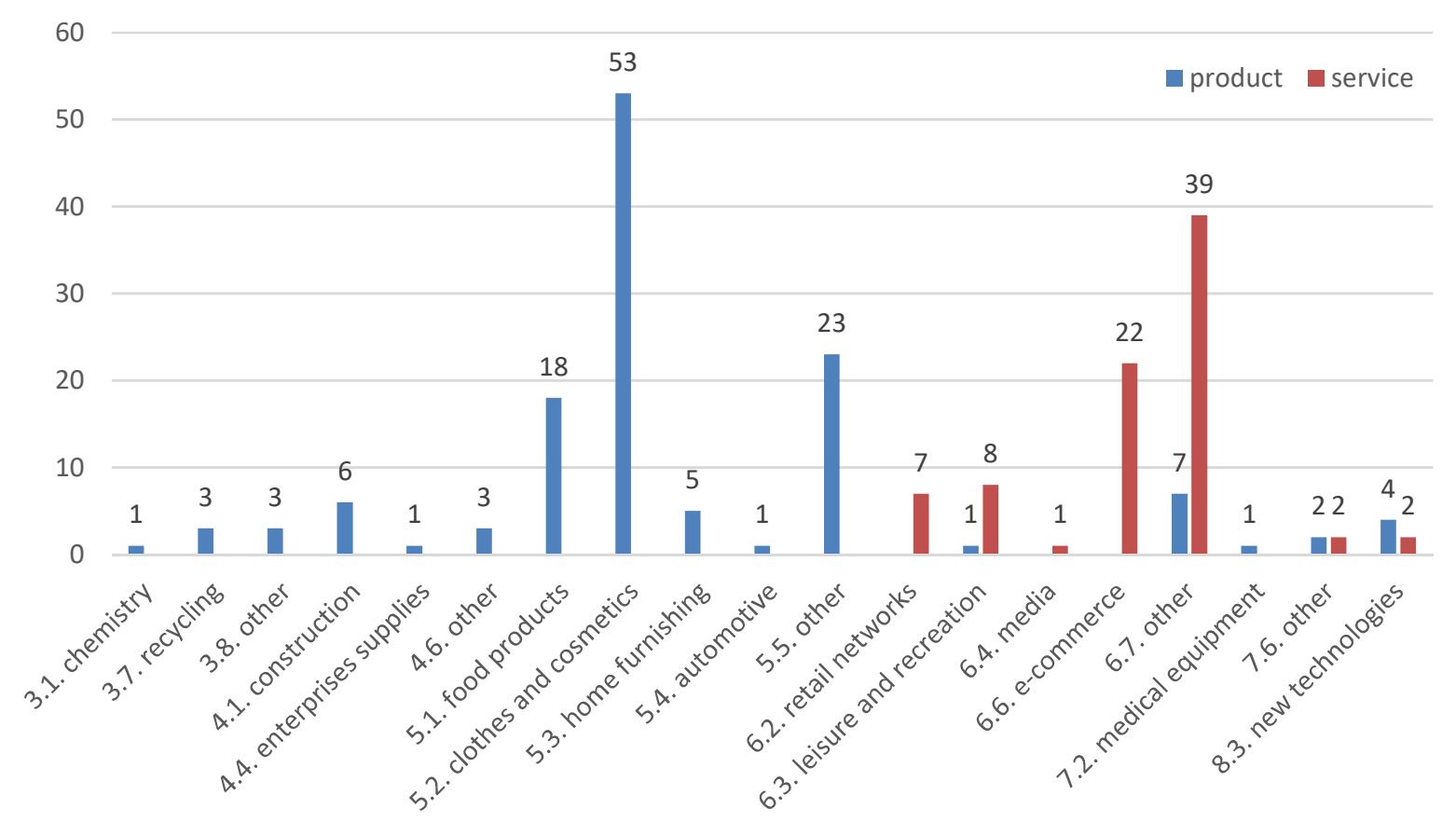

Figure 6. Number of enterprises in particular industries by product or service Source: own elaboration $(n=213)$.

\section{Part Two: Sustainable Development Start-ups in Terms of the Definition}

Among the analysed enterprises, slightly over $10 \%$ use new technologies. Almost half of this group (10 entities) are enterprises operating in the macro-sector of trade and services, out of which $80 \%$ have been classified as "other", which means that their business activities were not assigned to any category suggested in the classification. Another 5 entities are enterprises operating in the sector of new technologies.

The results confirm that the classification of enterprises used does not include innovative enterprises operating on the basis of various technological solutions, and the distinguished sector of new technologies is too narrow and does not include the possibilities and solutions available on the market.

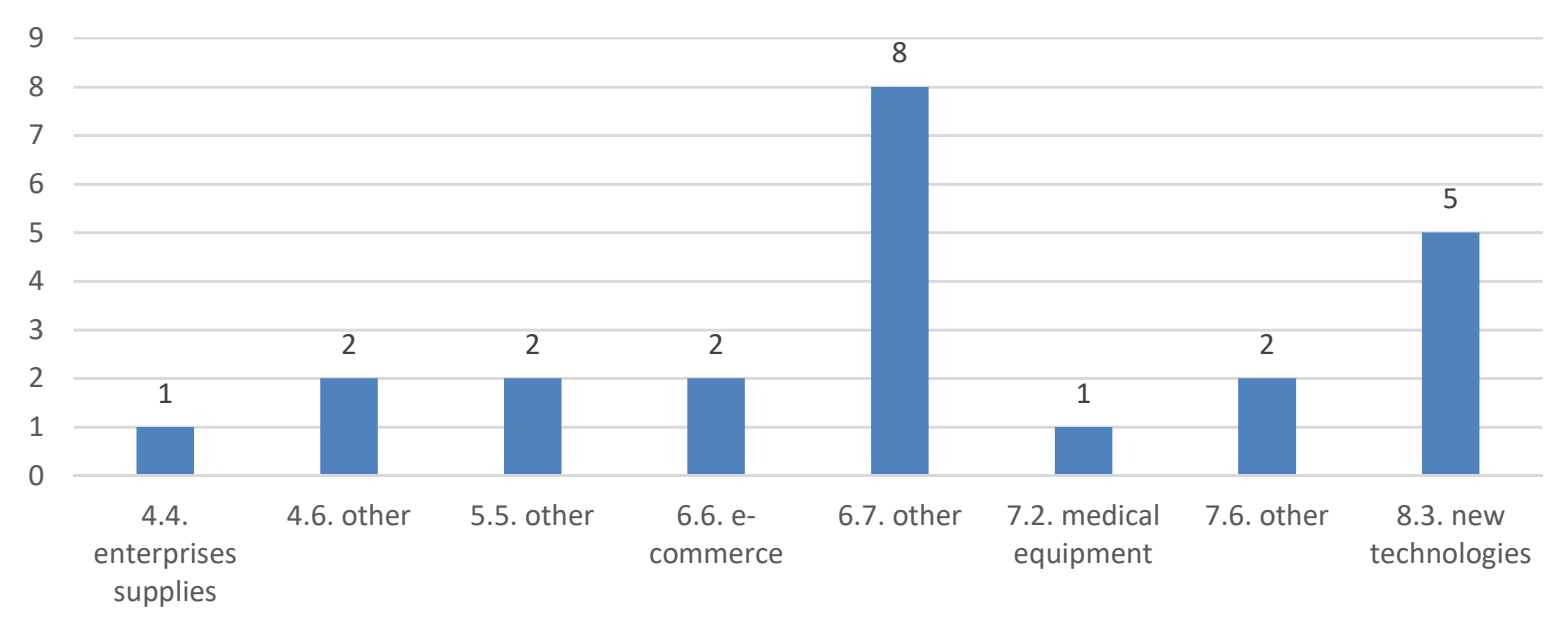

Figure 7. Number of enterprises in particular industries using new technologies Source: own elaboration $(n=213)$.

It should be noted that among the remaining enterprises which do not use new technologies, there is a trend of not only refraining from searching for new solutions, but also returning to solutions that had been known and used for many years, such as production based on natural raw materials or services offering renovation of items of different categories. 


\section{CONCLUSIONS}

The purpose of this research was to review entities operating on the basis of sustainable business models - the so-called Positive Impact Start-ups - in order to determine their scale and development potential and define a profile of such enterprises operating in Poland. The analysis was conducted on the basis of the Positive Impact Start-ups database. The entities listed in the database represent only an insignificant fraction of all enterprises operating in Poland. The results and formulated conclusions should be applied to the specific category of Positive Impact Start-ups and should not be used for making generalizations regarding enterprises in general.

On the basis of the analysis, it can be concluded that the number of Positive Impact Start-ups is constantly growing, by about 20-30 entities year on year. Although from the perspective of the analysed group, it represents a significant increase, in relation to the total number of enterprises operating in individual industries it is insignificant, and over the last four years there has been no significant change in the trend. Without additional factors motivating entrepreneurs to integrate social and environmental aspects into their business models, such as consumer awareness and pressure or regulations, no significant, large-scale changes are likely to emerge in business models of enterprises.

Based on the analysed data, a profile of a Positive Impact Start-up was created with the most typical characteristics of this type of enterprise. A profile is a set of features that are most frequent within each analysed category.

Positive Impact Start-up Profile:

- establishment year: established within the last 5 years (in 2015-2019),

- location: established in a large city,

- industry: operates in the manufacturing industry, producing clothing, cosmetics or food products, or in the clothing industry, but its business operation cannot be clearly classified into a specific category,

- the use of new technologies: does not use new technologies. The only technological solution used are websites and online stores, often created on the basis of ready-made templates.

In many cases, the analysed Positive Impact Start-ups are small manufacturing companies, online shops or other enterprises that take a competitive advantage of their small-scale, which is clearly reflected in their missions or visions. These are not so much scalable as replicable businesses, while these are the characteristics of start-ups (Sekliuckiene et al., 2018; Maciejewski \& Wach, 2019). It is possible to open many similar enterprises. In light of the above, there are doubts regarding the compliance of the enterprises listed in the database with the definition of a Positive Impact Start-up, proposed by the authors of the database, according to which such enterprises not only "contribute to a rapid increase in the quality of life and the environment within the sphere of their influence", but also achieve a "rapid growth of the value of the company/organization".

Regardless of the current scale and the scope of their business activity, it can be concluded that the number of enterprises in Poland based on sustainable business models that take into account specific social and environmental aspects is growing. In order to understand the potential of this phenomenon, further research with more precise criteria and more careful analysis.

Possible areas of further research include:

1. Extension of the subject scope of the analysis. Including large enterprises: Due to the scale of operations, the impact of solutions introduced by large enterprises is much greater. Such solutions can serve as an example and inspiration for new enterprises.

2. Extension of the subject scope of the analysis: Including a larger number of enterprises operating in the B2B model. In the Positive Impact Start-ups database, enterprises operating in the B2C model are dominating. This does not reflect the structure of the market. The market of start-ups offering solutions for enterprises, which is an extremely important element in building the business ecosystem of sustainable development, was largely disregarded. Analysing the phenomenon of Positive Impact Start-ups against the market as a whole will allow to fully diagnose its scale and significance, and to propose adequate recommendations regarding its development. 
3. Clarification of the definition and criteria characterizing sustainable development enterprises: Both the analysis of the literature on the subject, as well as the review of the Positive Impact Start-ups database, indicates the need for the clarification of the definition of a sustainable development enterprise, including the purpose of its operation and scope of business activities, and thus to determine whether enterprises from such sectors as medicine, pharmacy or education should always be considered as sustainable development enterprises due to their goal, which is improving health and quality of life or offering equal access to education, or whether they should undertake additional measures in order to be qualified in this category.

\section{REFERENCES}

Balbinot, Z., \& Borim-De-Souza, R. (2012). Sustainable development and sustainability as quasi-objects of study in management: A search for styles of reasoning. Management Research, 10(3), 153-186. https://doi.org/10.1108/1536-541211273856

Battistella, C., De Toni, A. F., De Zan, G., \& Pessot, E. (2017). Cultivating business model agility through focused capabilities: A multiple case study. Journal of Business Research, 73, 65-82. https://doi.org/10.1016/j.jbusres.2016.12.007

Beckmann, M., Hielscher, S., \& Pies, I. (2014). Commitment Strategies for Sustainability: How Business Firms Can Transform Trade-Offs Into Win-Win Outcomes. Business Strategy and the Environment, 23(1), 18-37. https://doi.org/10.1002/bse.1758

Bocken, N.M.P, Short, S., Rana, P., \& Evans, S. (2013). A value mapping tool for sustainable business modelling. Corporate Governance (Bingley), 13(5), 482-497. https://doi.org/10.1108/CG-06-2013-0078

Bocken, N.M.P., Short, S. W., Rana, P., \& Evans, S. (2014). A literature and practice review to develop sustainable business model archetypes. Journal of Cleaner Production, 65, 42-56. https://doi.org/10.1016/j.jclepro.2013.11.039

Bocken, N.M.P., de Pauw, I., Bakker, C., \& van der Grinten, B. (2016). Product design and business model strategies for a circular economy. Journal of Industrial and Production Engineering, 33(5), 308-320. https://doi.org/10.1080/21681015.2016.1172124

Boons, F., \& Lüdeke-Freund, F. (2013). Business models for sustainable innovation: State-of-the-art and steps towards a research agenda. Journal of Cleaner Production, 45, 9-19. https://doi.org/10.1016/j.jclepro.2012.07.007

Bradley, P., Parry, G., \& O’Regan, N. (2020). A framework to explore the functioning and sustainability of business models. Sustainable Production and Consumption, 21, 57-77. https://doi.org/10.1016/j.spc.2019.10.007

Chesbrough, H. (2007). Business model innovation: It's not just about technology anymore. Strategy and Leadership, 35(6), 12-17. https://doi.org/10.1108/10878570710833714

Christofi, A., Christofi, P., \& Sisaye, S. (2012). Corporate sustainability: Historical development and reporting practices. Management Research Review, 35(2), 157-172. https://doi.org/10.1108/01409171211195170

Ciulli, F., \& Kolk, A. (2019). Incumbents and business model innovation for the sharing economy: Implications for sustainability. Journal of Cleaner Production, 214, 995-1010. https://doi.org/10.1016/j.jclepro.2018.12.295

Dabbous, A., \& Tarhini, A. (2019). Assessing the impact of knowledge and perceived economic benefits on sustainable consumption through the sharing economy: A sociotechnical approach. Technological Forecasting and Social Change, 149(July), 119775. https://doi.org/10.1016/j.techfore.2019.119775

Elkington, J. (1998). Partnerships from cannibals with forks: The triple bottom line of 21st-century business. Environmental Quality Management, 8(1), 37-51. https://doi.org/10.1002/tqem.3310080106

Ellen MacArthur Foundation, \& McKinsey Center for Business and Environment. (2015). Growth within: a circular economy vision for a competitive Europe.

Euroactiv.pl (2018). Gospodarka o obiegu zamkniętym. Nowy plan dla Europy. Retrieved from: https://odpowiedzialnybiznes.pl/wp-content/uploads/2019/06/EA-SPECIAL-REPORT-EURACTIV-PL-V01.pdf on: 06.10 .2020 
Ferreira, J.J.M., Fernandes, C.I., \& Ferreira, F.A.F. (2020). Technology transfer, climate change mitigation, and environmental patent impact on sustainability and economic growth: A comparison of European countries. Technological Forecasting and Social Change, 150(November 2019), 119770. https://doi.org/10.1016/j.techfore.2019.119770

Foss, N.J., \& Saebi, T. (2017). Fifteen Years of Research on Business Model Innovation: How Far Have We Come, and Where Should We Go? Journal of Management, 43(1), 200-227. https://doi.org/10.1177/0149206316675927

Galpin, T., Whittington, J. L., \& Bell, G. (2015). Is your sustainability strategy sustainable? Creating a culture of sustainability. Corporate Governance (Bingley), 15(1), 1-17. https://doi.org/10.1108/CG-01-2013-0004

GUS (2019). Monitoring Rynku Pracy - informacja o rynku pracy w trzecim kwartale 2019.

Joyce, A., \& Paquin, R. L. (2016). The triple layered business model canvas: A tool to design more sustainable business models. Journal of Cleaner Production, 135, 1474-1486. https://doi.org/10.1016/j.jclepro.2016.06.067

Kagawa, F. (2007). Dissonance in students' perceptions of sustainable development and sustainability: Implications for curriculum change. International Journal of Sustainability in Higher Education, 8(3), 317-338. https://doi.org/10.1108/14676370710817174

Kolk, A., \& Mauser, A. (2002). The evolution of environmental management: From stage models to performance evaluation. Business Strategy and the Environment, 11(1), 14-31. https://doi.org/10.1002/bse.316

KPMG (2018). Rynek mody w Polsce. https://assets.kpmg/content/dam/kpmg/pl/pdf/2018/11/pl-Raport-KPMGpt-Rynek-mody-w-polsce.pdf

Le Trinh, T. (2019). Factors affecting startup performance of small and medium-sized enterprises in Danang city. Entrepreneurial Business and Economics Review, 7(3), 187-203. https://doi.org/10.15678/EBER.2019.070310

Lélé, S. M. (1991). Sustainable development: A critical review. World Development, 19(6), 607-621. https://doi.org/10.1016/0305-750X(91)90197-P

Maciejewski, M., \& Wach, K. (2019). International Startups from Poland: Born Global or Born Regional?. Journal of Management and Business Administration Central Europe, 27(1), 60-83. https://doi.org/10.7206/jmba.ce.2450-7814.247

Morioka, S.N., Evans, S., \& de Carvalho, M.M. (2016). Sustainable Business Model Innovation: Exploring Evidences in Sustainability Reporting. Procedia CIRP, 40,659-667. https://doi.org/10.1016/j.procir.2016.01.151

Osterwalder, A., \& Pigneur, Y. (2010). Business Model Generation - Canvas. Wiley.

Osterwalder, A., Pigneur, Y., \& Tucci, C. L. (2005). Clarifying Business Models: Origins, Present, and Future of the Concept. Communications of the Association for Information Systems, 16(1), 1-25. https://doi.org/10.17705/1cais.01601

Prendeville, S., \& Bocken, N. (2017). Sustainable Business Models through Service Design. Procedia Manufacturing, 8(October 2016), 292-299. https://doi.org/10.1016/j.promfg.2017.02.037

Press, M., Robert, I., \& Maillefert, M. (2020). The role of linked legitimacy in sustainable business model development. Industrial Marketing Management, 89, 566-577. https://doi.org/10.1016/j.indmarman.2019.05.009

Rafiei, M., \& Ricardez-Sandoval, L. A. (2020). New frontiers, challenges, and opportunities in integration of design and control for enterprise-wide sustainability. Computers and Chemical Engineering, 132. https://doi.org/10.1016/j.compchemeng.2019.106610

Reinhardt, R., Christodoulou, I., Gassó-Domingo, S., \& Amante García, B. (2019). Towards sustainable business models for electric vehicle battery second use: A critical review. Journal of Environmental Management, 245(June), 432-446. https://doi.org/10.1016/j.jenvman.2019.05.095

Richardson, J. (2008). The business model: an integrative framework for strategy execution. Strategic Change, 17(5-6), 133-144. https://doi.org/10.1002/jsc.821

Rok, B., Andrzejewska, A., Jachna, P., Osytek, A., Panek-Owsiańska, M., Pokora, A., \& Wrzosek, A. (2019). Startupy pozytywnego wpływu. Radykalna innowacja społeczna. http://raportspw.kozminskihub.com/public/docs/Raport SPW 2019.pdf

Sala, S., Ciuffo, B., \& Nijkamp, P. (2015). A systemic framework for sustainability assessment. Ecological Economics, 119, 314-325. https://doi.org/10.1016/j.ecolecon.2015.09.015

Sancha, C., Gimenez, C., \& Sierra, V. (2016). Achieving a socially responsible supply chain through assessment and collaboration. Journal of Cleaner Production, 112, 1934-1947. https://doi.org/10.1016/j.jclepro.2015.04.137 
Schaltegger, S., Hansen, E. G., \& Lüdeke-Freund, F. (2016). Business Models for Sustainability: Origins, Present Research, and Future Avenues. In Organization and Environment (Vol. 29, Issue 1). https://doi.org/10.1177/1086026615599806

Sekliuckiene, J., Vaitkiene, R., \& Vainauskiene, V. (2018). Organisational learning in startup development and international growth. Entrepreneurial Business and Economics Review, 6(4), 125-144. https://doi.org/10.15678/EBER.2018.060407

Sheehan, M., Garavan, T. N., \& Carbery, R. (2014). Guest editorial: Sustainability, corporate social responsibility and HRD. European Journal of Training and Development, 38(5), 370-386. https://doi.org/10.1108/EJTD-04-2014-0034

Skowroński, A. (2006). Zrównoważony rozwój perspektywą dalszego postępu cywilizacyjnego Sustainable development as the perspective of further civilisation development. Problemy Ekorozwoju, 1(2), 47-57.

Smith, P. A. C., \& Sharicz, C. (2011). The shift needed for sustainability. Learning Organization, 18(1), 73-86. https://doi.org/10.1108/09696471111096019

Stanek-Kowalczyk, A. (2012). Zrównoważony rozwój i społeczna odpowiedzialność biznesu. Definicje i standardy a świadomość polskich firm. In M. Cisek \& M. Wakuła (Eds.), Odpowiedzialne zarzqdzanie: wybrane aspekty (pp. 25-37). Studio Emka.

Teece, D. J. (2010). Business models, business strategy and innovation. Long Range Planning, 43(2-3), $172-194$. https://doi.org/10.1016/j.Irp.2009.07.003

Upward, A., \& Jones, P. (2016). An Ontology for Strongly Sustainable Business Models: Defining an Enterprise Framework Compatible With Natural and Social Science. Organization and Environment, 29(1), 97-123. https://doi.org/10.1177/1086026615592933

Viciunaite, V., \& Alfnes, F. (2020). Informing sustainable business models with a consumer preference perspective. Journal of Cleaner Production, 242, 118417. https://doi.org/10.1016/j.jclepro.2019.118417

Wach, K. (2020). A typology of small business growth modelling: A critical literature review. Entrepreneurial Business and Economics Review, 8(1), 159-184. https://doi.org/10.15678/EBER.2020.080109

World Commission on Environment and Development. (1987). Report of the World Commission on Environment and Development: Our Common Future (The Brundtland Report). https://doi.org/10.1080/07488008808408783

Yip, A. W. H., \& Bocken, N. M. P. (2018). Sustainable business model archetypes for the banking industry. Journal of Cleaner Production, 174, 150-169. https://doi.org/10.1016/j.jclepro.2017.10.190

Zott, C., Amit, R., \& Massa, L. (2011). The business model: Recent developments and future research. Journal of Management, 37(4), 1019-1042. https://doi.org/10.1177/0149206311406265 


\section{Author}

\section{Aleksandra Stanek-Kowalczyk}

Assistant Professor at Warsaw School of Economics. Her research interests include sustainable business, sustainable business models, sustainability reporting, sustainable finance.

Correspondence to: dr Aleksandra Stanek-Kowalczyk, Collegium of Management and Finance, Management Institute, Warsaw School of Economics, ul. Madalińskiego 31/33 DS Grosik, pok. 125, 02-513 Warszawa, Poland email: aleksandra.stanek-kowalczyk@sgh.waw.pl

ORCID (1) http://orcid.org/0000-0002-1530-5451

\section{Conflict of Interest}

The author declares that the research was conducted in the absence of any commercial or financial relationships that could be construed as a potential conflict of interest.

\section{Copyright and License}

This article is published under the terms of the Creative Commons

Attribution - NoDerivs (CC BY-ND 4.0) License

http://creativecommons.org/licenses/by-nd/4.0/ 
